MICHAEL C. LOVELL

Wesleyan University

\title{
The Profit Picture: Trends and Cycles
}

HAS THERE BEEN a squeeze on profits during the past decade? And if profits have been under pressure, what has been the primary source of the squeeze? These are important questions, not only for stockholders, but also for the economy as a whole. If George Perry was correct in stating that profits are an important determinant of money wages in manufacturing, a squeeze on profits might serve to dampen wage demands, which would mitigate inflationary pressure. If profits, by stimulating investment spending, trickle down into greater productivity, a squeeze on profits may lead to less output per man-hour, which would intensify inflation. And if William Baumol is correct in arguing that the profits realized by the firm are more than a residual, a squeeze on profits has unfortunate implications for price movements and employment. According to Baumol's proposition that firms maximize sales volume subject to a profit constraint, a squeeze on profits is likely to induce a rise in prices along with a simultaneous contraction in output and employment. ${ }^{1}$ Recently, complaints about a profit squeeze, coupled with a concern that investment levels are inadequate and the decline in productivity growth, have brought intensified pressure for a reduction in the corporate tax rate and a more generous investment tax credit.

1. William J. Baumol, Economic Theory and Operations Analysis, 4th ed. (Prentice-Hall, 1977), chap. 15. Herbert A. Simon's satisficing theory suggests that a profit squeeze eats into organizational slack and encourages a deeper look at the corporation's accustomed practices; it may lead to a tightening of pricing policy and a search for ways of increasing the efficiency of operations. See Herbert Simon, "Theories of Decision-Making in Economics and Behavioral Science," American Economic Review, vol. 49 (June 1959), pp. 253-83. 
Arthur M. Okun and George L. Perry point out in their 1970 paper, "Notes and Numbers on the Profits Squeeze," that, before the mid-1960s, the share of corporate profits in gross national product could be explained quite precisely by fluctuations in the percentage shortfall between realized and potential GNP. ${ }^{2}$ In this report I decompose the movements of a variety of alternative profit measures into trend and cyclical forces. It turns out that whether a profit squeeze has actually occurred, its intensity and the extent of profit recovery in recent years depends largely upon how this multifaceted concept is defined and measured.

\section{Profit Measures}

Profits can be measured in relation to equity, the capital stock, or value added. They can be measured directly from tax accounting records or with corrections for the diversity of conventional accounting procedures and with adjustments for some distorting effects of inflation. Profits can be narrowly defined as the return on equity capital or more generically measured to include the interest costs on borrowed capital.

Table 1 lists fourteen alternative concepts for measuring profits. The eight profit measures listed across the first two rows are for the share of profits in the income generated by nonfinancial corporate business. The first four of these measures $(P a, P I a, P A T a$, and $P I A T a)$ are adjusted for variations in accounting procedures; all inventories are measured to approximate last-in-first-out (LIFO) accounting, and the capital consumption allowance is based on replacement rather than historical cost and on the estimated economic lives of assets rather than the service lives allowed for tax purposes. Two of the adjusted profit shares include interest payments; two measures are net of the corporate profits tax. The PIATa profit measure-profits plus interest after tax-corresponds to the "genuine profit" concept used by William Nordhaus in his study, "The Falling Share of Profits."

The measures listed in the second row (Pc, PIc, PATc, and PIATc) are based on the conventional accounting figures used by business firms,

2. $B P E A, 3: 1970$, pp. 466-72.

3. William D. Nordhaus, "The Falling Share of Profits," BPEA, 1:1974, pp. 169208. 
Table 1. Alternative Concepts for Measuring Profits

\begin{tabular}{|c|c|c|c|c|}
\hline \multirow[b]{2}{*}{ Description } & \multicolumn{4}{|c|}{ Concept } \\
\hline & Profits & $\begin{array}{l}\text { Profits } \\
\text { plus } \\
\text { interest }\end{array}$ & $\begin{array}{l}\text { Profits } \\
\text { after } \\
\text { corporate } \\
\text { profits } \\
\text { tax }\end{array}$ & $\begin{array}{c}\text { Profits } \\
\text { plus } \\
\text { interest } \\
\text { after } \\
\text { corporate } \\
\text { profits tax }\end{array}$ \\
\hline \multicolumn{5}{|l|}{ Share of profits (nonfinancial corporations) } \\
\hline $\begin{array}{l}\text { With inventory valuation and capital } \\
\text { consumption adjustments }\end{array}$ & $\mathrm{Pa}$ & PIa & $P A T a$ & PIATa \\
\hline $\begin{array}{l}\text { Using conventional accounting } \\
\text { procedures }\end{array}$ & $P c$ & PIc & $P A T c$ & PIATC \\
\hline \multicolumn{5}{|l|}{$\begin{array}{l}\text { Rate of return on equity (manufacturing } \\
\text { firms) }\end{array}$} \\
\hline $\begin{array}{l}\text { Using data from FTC-SEC quarterly } \\
\text { financial reports }{ }^{\mathrm{a}} \text { and conventional } \\
\text { accounting procedures }\end{array}$ & $R O E m$ & $\cdots$ & $R O E A T m$ & $\cdots$ \\
\hline \multicolumn{5}{|l|}{$\begin{array}{l}\text { Rate of return relative to capital stock } \\
\text { (nonfinancial corporations) }\end{array}$} \\
\hline $\begin{array}{l}\text { With inventory valuation and capital } \\
\text { consumption adjustments }\end{array}$ & $\cdots$ & RPIa & $\ldots$ & RPIATa \\
\hline $\begin{array}{l}\text { Using conventional accounting } \\
\text { procedures }\end{array}$ & $\cdots$ & RPIc & $\cdots$ & RPIATc \\
\hline
\end{tabular}

Sources: See appendix for sources and for a more detailed description of the profit concepts.

a. Federal Trade Commission-Securities and Exchange Commission, Quarterly Financial Report for Manufacturing Corporations; currently, Federal Trade Commission, Quarterly Financial Report for Manufacturing, Mining and Trade Corporations.

at least for tax purposes. PIATc corresponds to the "nominal share" concept of the Nordhaus study.

The two profit concepts in the third row, $R O E m$ and $R O E A T m$, are rates of return on equity as reported by U.S. manufacturing firms to the joint Federal Trade Commission-Securities and Exchange Commission publication (since 1971, Federal Trade Commission only), Quarterly Financial Report. These are both nominal book measures reflecting the diversity of accounting practices. The ROEATm concept was used by Perry in his study of the determinants of money wages."

4. George L. Perry, Unemployment, Money Wage Rates, and Inflation (MIT Press, 1966). A similar measure is used by Laurence S. Seidman in "Tax-Based Incomes Policies," BPEA, 2:1978, pp. 301-48. 
The four profit measures in the bottom two rows of the table are ratios of profits plus interest for nonfinancial corporations relative to Musgrave's estimates of the value of equipment stock plus structures. ${ }^{5}$ The RPIa measure corresponds to that used by Feldstein and Summers in their study, "Is the Rate of Profit Falling?"

While none of the profit measures is without merit, some may be more informative than others. During times of inflation, conventional accounting estimates are subject to a variety of distortions; some of these distortions may understate profits, while others may exaggerate them. First-infirst-out (FIFO) inventory accounting and historical cost depreciation overstate profits. Accelerated depreciation and the neglect of the inflationinduced decline in the real value of the firm's financial obligations contribute to understatement. Conceivably, these two offsetting types of error may more or less cancel out. ${ }^{7}$ It is especially difficult to characterize the $R O E m$ and ROEATm concepts because the profits are measured relative to conventional accounting estimates of corporate equity, and because both numerator and denominator are affected by inflation, but not in a directly offsetting way.

The adjusted profit series, identified with an $a$ in table 1, incorporate two national income accounting refinements of the conventionally measured book figures. The capital consumption adjustment (CCA) makes two corrections that go in opposite directions. It raises profits by eliminating accelerated depreciation and, of greater importance in recent years, lowers them by converting from historical cost to replacement cost depreciation. The inventory valuation adjustment (IVA) corrects for the vagaries of inventory accounting procedures by calculating profits uniformly as though all firms used LIFO accounting. This latter correction

5. John C. Musgrave, "Fixed Nonresidential Business and Residential Capital in the United States, 1925-75," Survey of Current Business, vol. 56 (April 1976), p. 49. His data are updated in the August 1976 and August 1977 (vol. 57) issues of the Survey of Current Business, pp. 64 and 57, respectively.

6. Martin Feldstein and Lawrence Summers, "Is the Rate of Profit Falling?" $B P E A, 1: 1977$, pp. 211-27. In contrast to the Feldstein-Summers measure, the denominator does not include the value of nonfinancial corporate landholdings or the stock of inventories. Consequently, the computed measure overestimates the rate of profit. The value of land may be approximately proportional to the value of included assets. The value of inventories may have a different cyclical movement than the value of included assets.

7. See George M. von Furstenberg and Burton G. Malkiel, "Financial Analysis in an Inflationary Environment," Journal of Finance, vol. 32 (May 1977), pp. 575-88. 
has been quite large during inflationary episodes: in 1974 the adjustment reduced the conventionally measured book profit figures by 30 percent.

While the inventory and capital consumption adjustments made by the national income accountants lead to more conservative profit estimates, the adjusted profit figures err in the direction of understatement. ${ }^{8}$ Inflation causes profit figures to understate and interest figures to exaggerate actual returns because the figures do not net out the declining real value of financial obligations. When inflation is generally anticipated, borrowers have to pay higher nominal interest rates to compensate lenders for the real capital losses they will suffer through the predicted erosion of the purchasing power of periodic interest and amortization payments. The national income accounts exaggerate the return to the lender because the higher interest cost is counted as income, while the inflation-induced real capital losses are neglected; profit attributed to owners is understated because the decline in the real value of the firm's liabilities is neglected, while the added interest cost is recognized. These considerations mean that measures of gross profits including interest payments (those in the second and fourth columns of table 1) are probably more reliable than measures of profits net of interest.

While the IVA may lead to an improved measure of profits by approximating uniform LIFO, it poses certain conceptual problems. A firm borrowing funds to finance speculative inventory holdings may suffer an apparent diminution of LIFO accounting profits even if the anticipated price rise eventually materializes. ${ }^{9}$ An alternative to LIFO accounting, the "constant-dollar FIFO" procedure recommended by Shoven and Bulow, ${ }^{10}$ counts the capital gain on inventory holdings as profits to the

8. John B. Shoven and Jeremy I. Bulow, "Inflation Accounting and Nonfinancial Corporate Profits: Financial Assets and Liabilities," BPEA, 1:1976, pp. 15-57. Also see Sidney Davidson and Roman L. Weil, "Inflation Accounting: Implications of the FASB Proposal," in Henry J. Aaron, ed., Inflation and the Income Tax (Brookings Institution, 1976), pp. 81-114.

9. Consider a company that correctly anticipates rising prices of raw materials. The firm increases its inventory of purchased materials from a customary threemonth supply to a four-month supply. During the accounting periods over which the company maintains its extended inventories, LIFO profits are reduced because the added carrying costs, including interest, are treated as current expense, while the capital gain is not counted until the speculative position is liquidated. The national income accounts never capture the capital gain because they do not catch the base change when stocks are liquidated.

10. John B. Shoven and Jeremy I. Bulow, "Inflation Accounting and Nonfinancial Corporate Profits: Physical Assets," BPEA, 3:1975, pp. 589-97. 


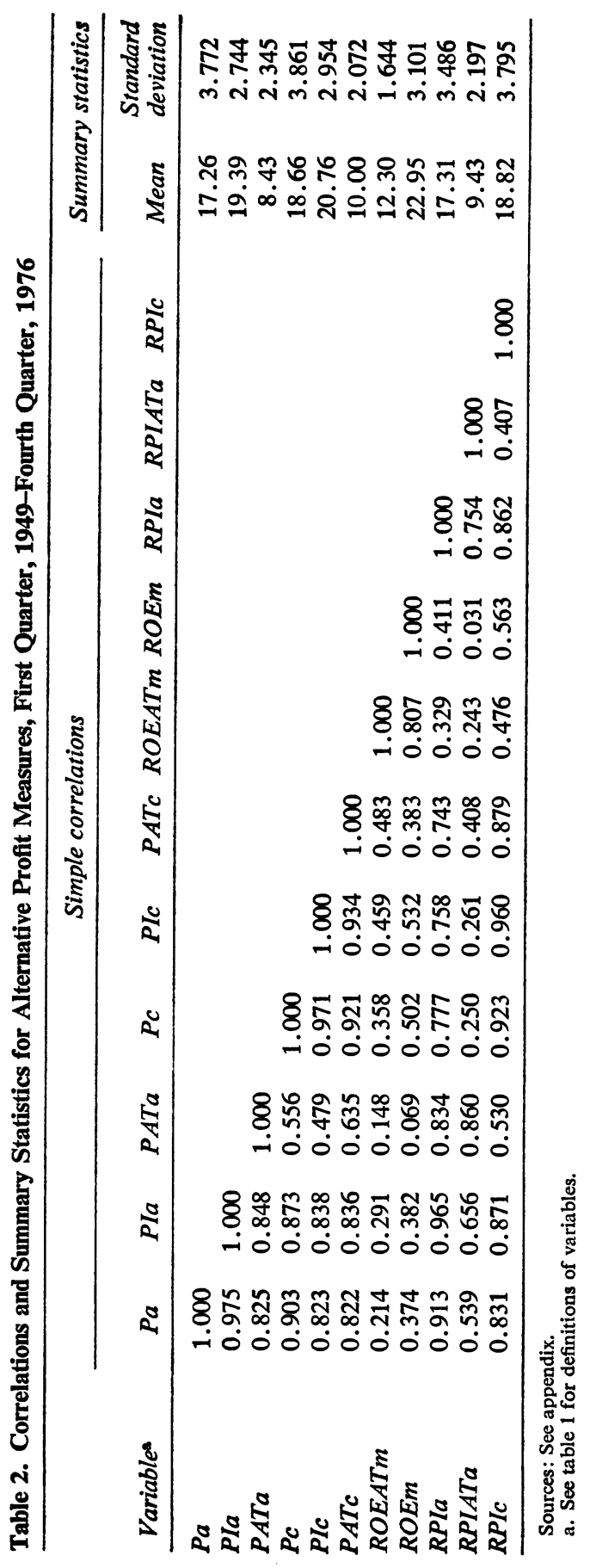


extent that they result from prices of the specific goods held by a firm rising more rapidly than the general inflation rate, as measured by the domestic spending deflator. A large difference exists between the estimate of Shoven and Bulow and the official LIFO estimates of profit for some years, such as 1974, when the price of goods held in inventory increased much more rapidly than the general price level. For 1974, instead of the official IVA writedown of book profits of nonfinancial corporations by $\$ 35.1$ billion, the constant-dollar FIFO writedown is only $\$ 16.2$ billion; thus Shoven and Bulow argue that the national income account estimate of 1974 nonfinancial corporate profits is understated by $\$ 18.9$ billion, or 17 percent of before-tax profits. Nonetheless, constant-dollar FIFO adjusted profits are not an appropriate guide for a firm contemplating the augmentation of stocks for speculative reasons because the relevant decision compares the rate of price change anticipated for the items to be held with the marginal carrying cost of inventories, including financing.

As these considerations indicate, there may be no single "ideal" profit measure. Rather than single out a preferred measure for exclusive scrutiny, this report looks at the common and distinguishing features of a variety of profit measures.

\section{Historical Overview}

Over the years the fourteen time series on profits have been only moderately synchronized. Table 2 reports the correlations among eleven of the profit measures. Generally the degree of correlation is not spectacularly high, which suggests that the apparent importance of profit variables in empirical studies of wage and price behavior might be sensitive to the particular profit measure employed. ${ }^{11}$ The two measures of manufacturing profit, $R O E m$ and $R O E A T m$, although closely correlated with each other, are not tightly related to the measures that refer to nonfinancial corporations and are not measured relative to equity. Among the nonfinancial corporate measures, those in the same rows of table 1-that is, those based on similar accounting procedures-are rather highly correlated.

11. My preliminary investigation tentatively suggests that the strongest influence on money wages may be exerted by the share of profits plus interest net of the corporate profits tax $(P I A T C)$, rather than by ROEATm, the FTC-SEC profit rate customarily employed in empirical studies of wage behavior. 


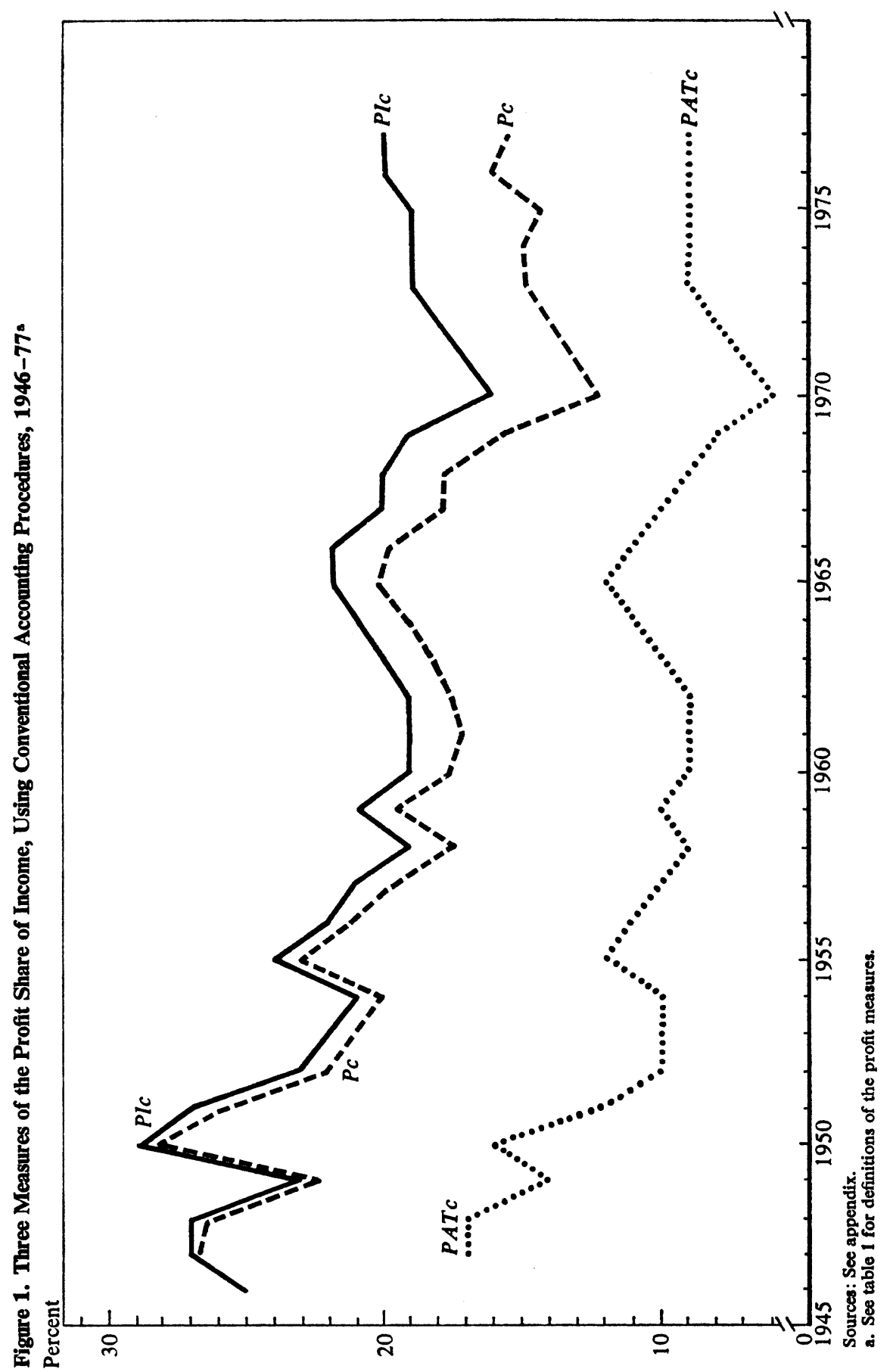


Three measures of the profit share of income are plotted in figure 1. Whether the profit share is measured gross or net of interest or before or after the corporate profits tax, the picture is one of declining profit shares from the end of World War II through the 1960s, followed by an upward trend toward partial recovery in the current decade. The more inclusive measure incorporating interest payments and profits shows a much more moderate declining trend over the years because of the growing importance of interest payments on borrowed capital. ${ }^{12}$ This growing interest share reflects changes in capitalization ratios as well as rising interest costs. The portion of the increase associated with rising interest costs is, in general, accompanied by a decline in the real value of outstanding debt.

Profit movements look quite different when the tax accounting measures are adjusted for inflation according to the procedures used in the GNP accounts. The $P a$ profit share in figure 2 involves the uniform evaluation of inventories on a LIFO basis and the consistent measure of the capital consumption allowance. While the $P a$ and the conventional $P c$ series usually move quite closely together, there are sizable discrepancies during the inflation of the post-World War II and Korean War periods and the 1970s. Inflationary profit euphoria is considerably dampened in the $P a$ series. The conventional accounting series, $P c$, exaggerated profits relative to the figures adjusted for inflation in the GNP accounts. In contrast to ROEATm, both $P a$ and $P c$ show a substantial squeeze on profits during the Vietnam period of the 1960 s, followed by a partial recovery in the 1970s.

\section{Trends and Cycles}

A convenient partitioning of the effects on alternative profit measures of shifting trend and cyclical movements is provided by the regressions reported in table 3 . The basic form of the regressions is:

$$
\text { (1) } \begin{aligned}
\log \text { (profit measure) }= & k_{1}+k_{2} \text { TREN } 47 \\
& +k_{3} \text { TREN } 65+k_{4} \text { TREN } 70+k_{5} G A P+\epsilon
\end{aligned}
$$

where $\epsilon$ is an error term:

12. The lower standard deviations reported in table 2 for the more inclusive profit measures including interest payments are primarily the consequence of this reduction in trend. 


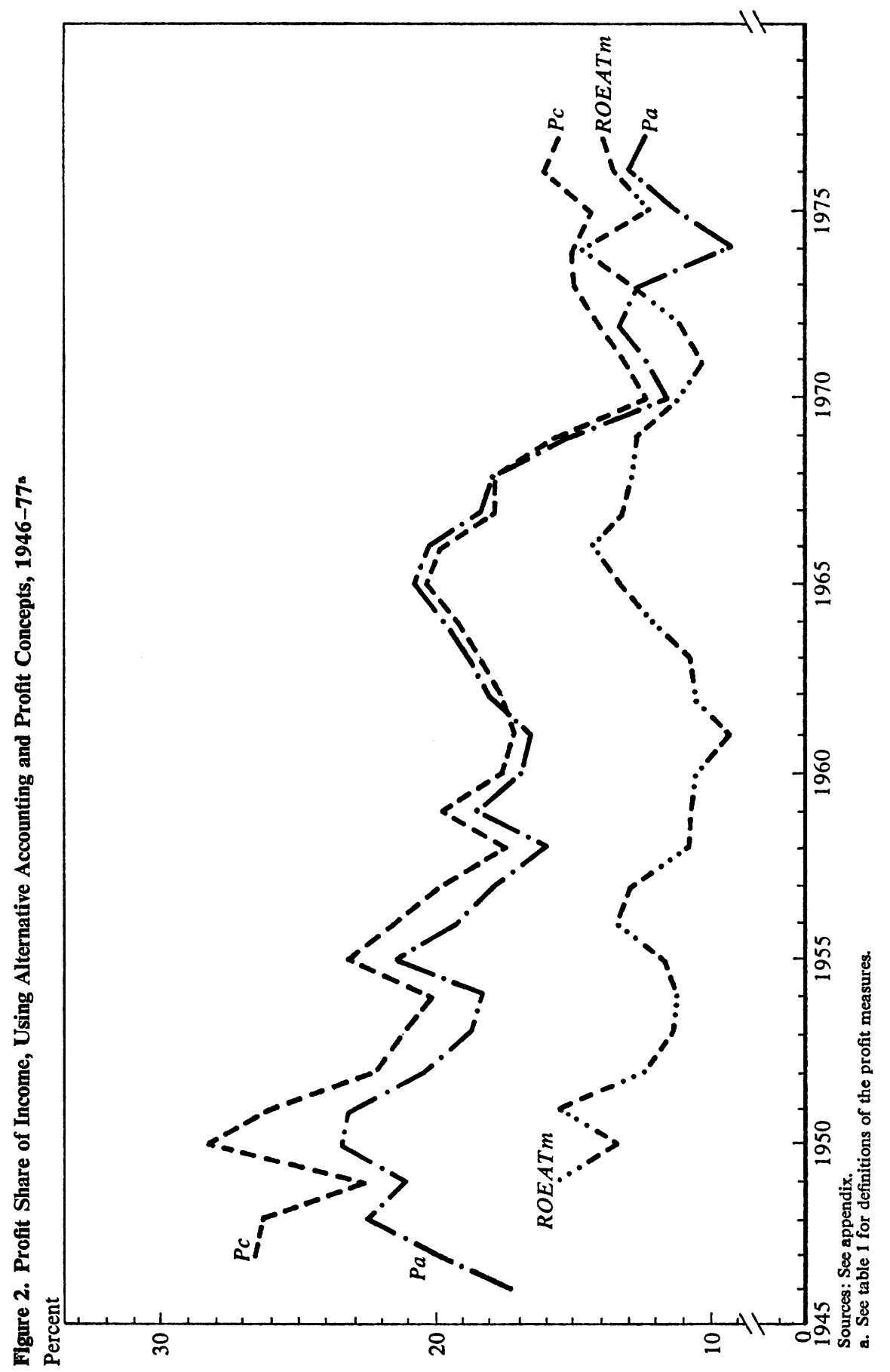


The effect of cyclical forces and stagnation are captured by the $G A P$ variable, which is the percentage shortfall between actual and potential GNP as estimated in the 1978 Economic Report of the President. ${ }^{13}$ The coefficients on the GAP variable are always negative, reflecting the general tendency for profits, however measured, to deteriorate during recession. Profit shares, return on equity, and profits relative to the capital stock all deteriorate in periods of economic slack. The magnitude of the $G A P$ regression coefficients indicates the relative sensitivity of the various profit measures to the business cycle. Those measures that are gross of interest payments are less cyclically sensitive than the net profit series. And the after-tax profit measures are generally less cyclically sensitive than the before-tax profit measures. The tendency of the corporate profits tax to smooth the profit stream may reflect a tendency for legislated changes in corporate taxes to be appropriately countercyclical rather than any built-in flexibility in the tax structure itself.

The other terms in the regression all relate to trend. The TREN 47 variable allows for steady compound interest growth or decay since World War II at an annual rate estimated by regression coefficient $k_{2}{ }^{14}$ The last two trend variables allow for a possible change in the growth trend during the Vietnam period in the 1960s (TREN 65) and again in the decade of the 1970s (TREN 70). Coefficients $k_{3}$ and $k_{4}$ measure the extent of the change. To illustrate, in the first regression of table 3 , there is a mild downward trend up to 1965 of $k_{2}=-1.2$ percent per year. Beginning in 1965 , the annual trend steepens to $k_{2}+k_{3}=-7.7$ percent. In the 1970s the profit slide is reversed, with the trend rising at an annual $k_{2}+k_{3}+k_{4}=1.7$ percent. The trends for the three periods for each of the profit measures are recorded at the bottom of the table.

13. Economic Report of the President, January 1978, p. 84. A quarterly potential GNP series was derived by interpolating the annual figures log linearly. The Durbin-Watson statistics obtained by running regression 1 are extremely small, indicating substantial autocorrelation in profits beyond what can be explained by cyclical forces. The $\rho$ coefficient measures the serial correlation of these residuals. The regressions reported in table 3 are performed on data subject to a CochraneOrcutt transformation to correct for the autocorrelated errors. Because 1 is a descriptive rather than a structural equation, the $t$-statistics reported directly below the regression coefficients must be interpreted with caution.

14. The TREN 47 variable is 0.25 in the first quarter of $1947,0.5$ in the second quarter, 0.75 in the third, and so on. That is, for the qth quarter of the yth year TREN $47=q / 4+y-47$. Because the log of the profit measure is the dependent variable, coefficient $k_{2}$ is the annual rate of growth compounded continuously. 


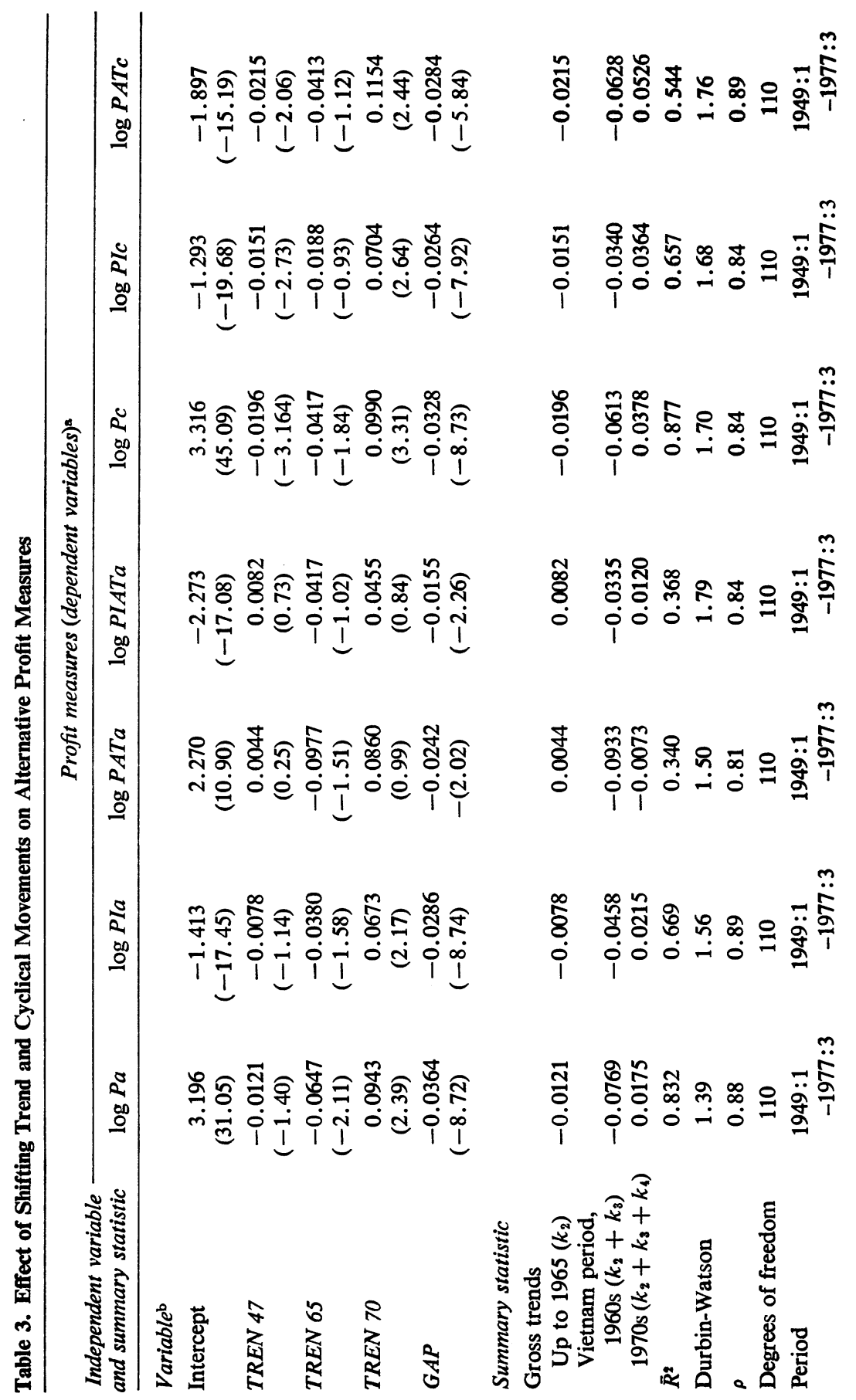




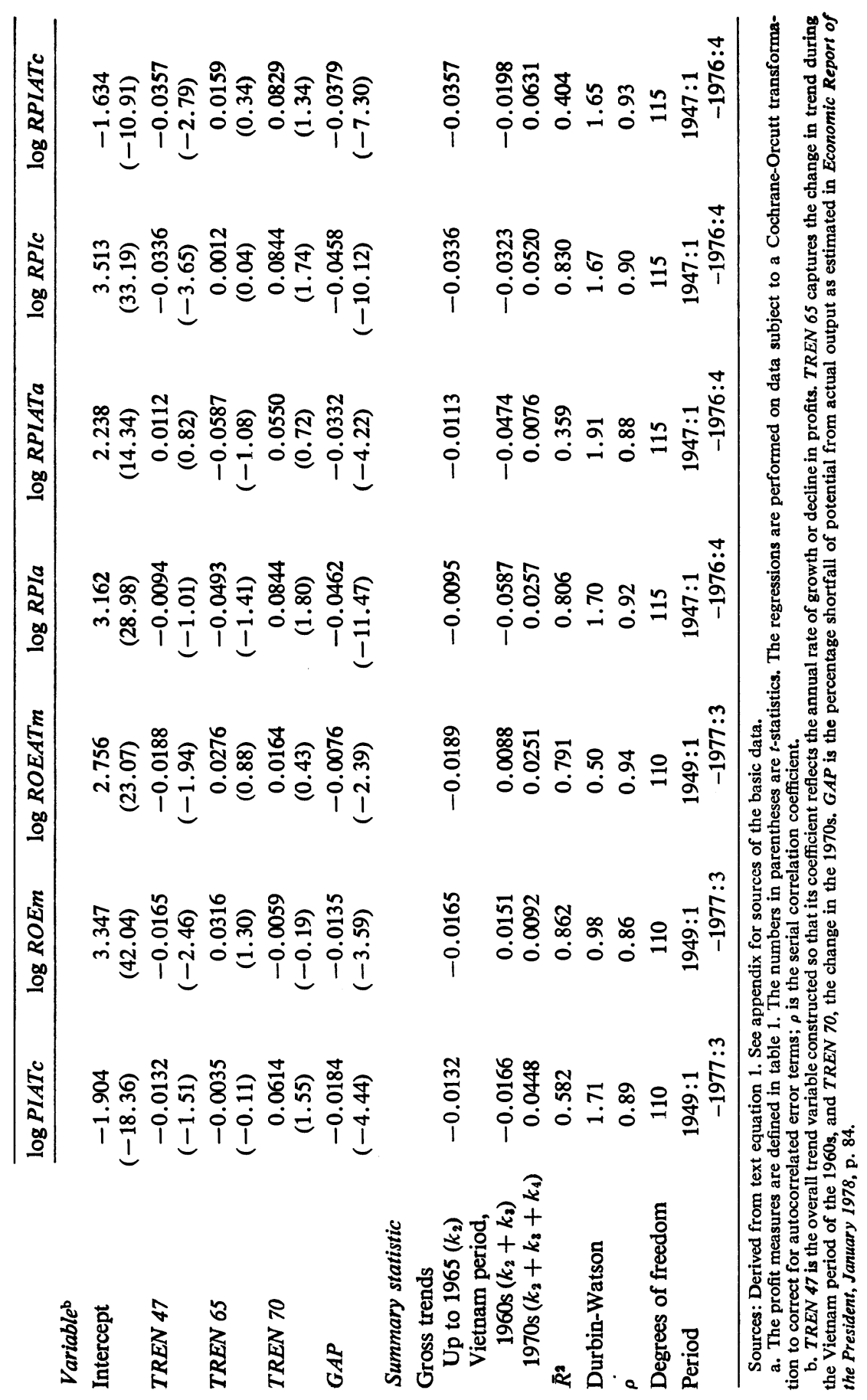


The regressions presented in table 3 help in describing shifting profit trends net of the cyclical forces captured by GAP. Several points deserve attention. First, most profit measures show a long-run declining trend over the decades $\left(k_{2}<0\right)$, but there are three exceptions to this observation. The exceptions-PATa, PIATa, and RPIATa-are all after-tax profit measures, and all are net of the IVA and CCA corrections. Because interest payments expanded secularly, the gross share measures, including interest as well as profits, tend to deteriorate less over the long run. Second, the Vietnam period steepened the declining trend in profits $\left(k_{2}+k_{3}<0\right)$. Two exceptions to this depressing squeeze are the FTCSEC manufacturing series, ROEm and ROEATm, both of which are unadjusted for the distortions of inflation. This means that if the profit measure ROEATm belongs in the wage equation, then the profit squeeze did not help to mitigate inflationary wage pressures. Third, the 1970s generally have not been characterized by a further deterioration of the profit picture. Only one of the fourteen measures, $P A T a$, has been subject to continuing deterioration. All profit measures using conventional accounting show particularly vigorous growth on a cyclically corrected basis.

\section{Productivity and Inflation}

A thorough understanding of profit movements requires the investigation of pricing strategy, wage determinants, material and energy cost movements, and the forces underlying the changing rate of productivity growth. Such an investigation is beyond the scope of this report. But the proximate causes of profit variations may be obtained by augmenting the profit-trend regressions. The ad hoc regressions in table 4 add the annual rates of productivity change and inflation. ${ }^{15}$

Changes in labor productivity would have no effect on profits if cost savings were immediately passed through to consumers in lower prices or absorbed by larger wage increases. The regressions in table 4 reveal that this is not what happens; rather, increases in labor productivity improve profits, with the exceptions of the two measures of manufacturing return on equity, ROEm and ROEATm. The regressions also suggest,

15. The nonfarm implicit price deflator and average labor productivity are used to measure inflation and productivity because these series are available quarterly for the entire period since World War II. 
again with two exceptions, that rising prices augment profits. ${ }^{16}$ If price increases were no more than an immediate pass-through of concurrent increases in labor and other costs, the rate of change in prices would have a negligible effect on profits. The positive coefficients of the price-change variable establishes that this is not what happens; in fact, price increases contribute to higher profits. It is not surprising to observe that changes in the rate of productivity growth and inflation influence the profit picture. What is most intriguing about the regressions in table 4 is that so many of the trend variables retain a major role in explaining movements in most of the profit measures, even when the changing rate of productivity growth, inflation, and the $G A P$ are included in the regressions. If the trend movements were generated by these variables, adding them to the regressions would have caused the trend explanatory variables to drop out. But the trend coefficients, although modulated, remain strong in table $4 .{ }^{17}$ It must be concluded that although the slowdown in productivity growth, inflation, and the $G A P$ have all had an impact on profits, these variables do not suffice to explain the dramatic drop in profits during the latter half of the 1960s and the recovery trend of the 1970s.

Table 5 illustrates the relative importance for profitability of the business cycle, the slowdown in productivity growth, and inflation for one of the profit series. The first column is the actual PIa series, the profits plus interest share net of the IVA and CCA. The remaining series are synthetic. The first synthetic series shows how the PIa profit share would have moved in the absence of the business cycle. The GAP adjustment smooths the recession-induced troughs in the profit share. But while part of the movement in the profit share is cyclically determined, the cycle is not the entire story of the changing profit share. The next column adjusts for the effect of the slowdown in productivity growth as well as the

16. The coefficients on price changes are larger in the regressions with conventionally measured profits than in those with the IVA and CCA adjusted series; this is presumably because the adjusted measures give a conservative picture of profits relative to the others in times of inflation.

17. Daniel M. Holland and Stewart C. Myers, in examining "Trends in Corporate Profitability and Capital Costs," a study to be published by the Committee for Economic Development, estimate trends in the rate of return on the capital stock, which they calculate as the ratio of profits plus interest net of the IVA and CCA to plant and equipment plus inventories. They obtain a $t$-statistic on trend of -0.26 for after-tax profits, which resembles the RPIATa profit measure; for their beforetax measure, which resembles RPIa, their $t$-statistic is -1.26 . They do not allow for bends in their trend line. 


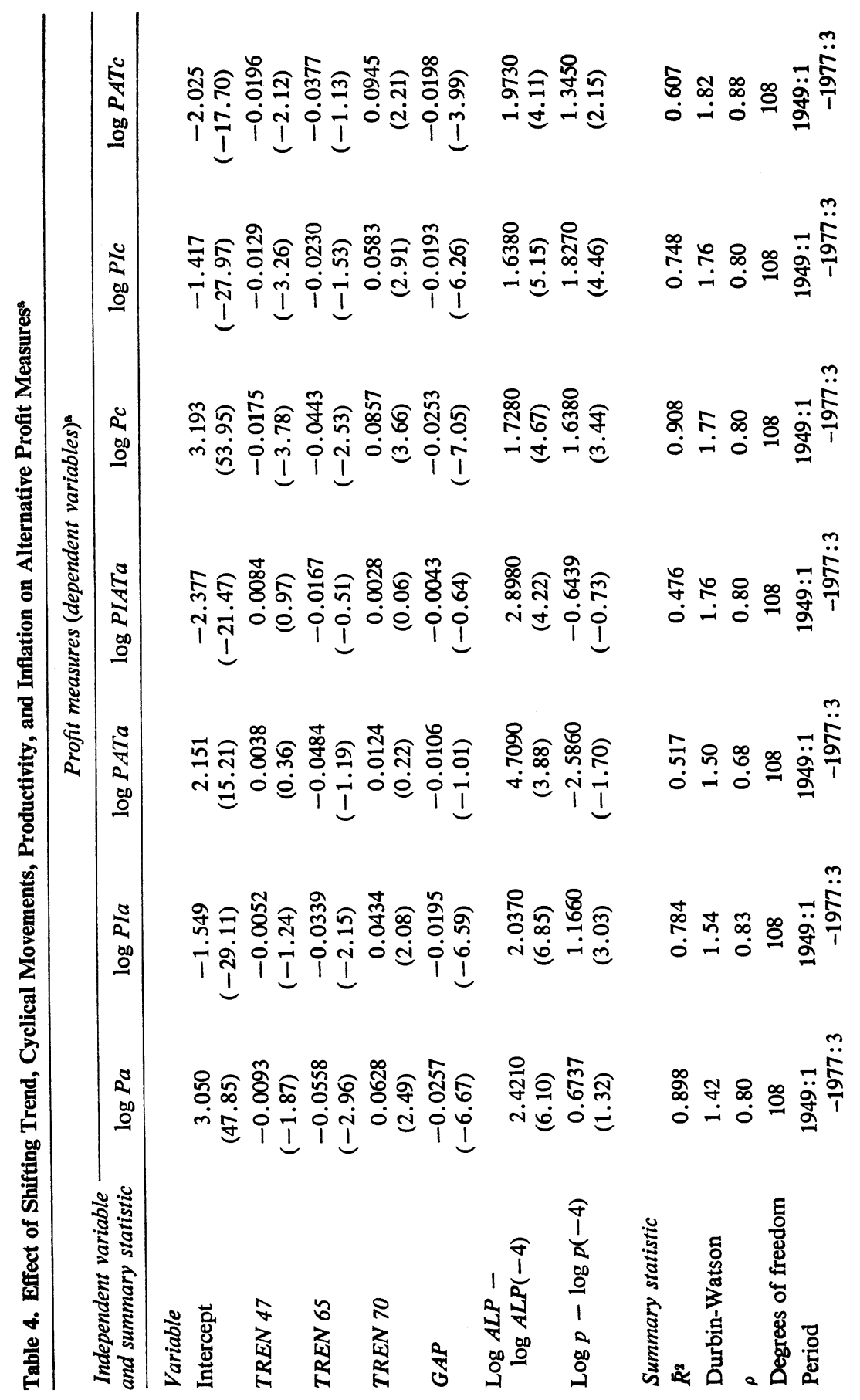




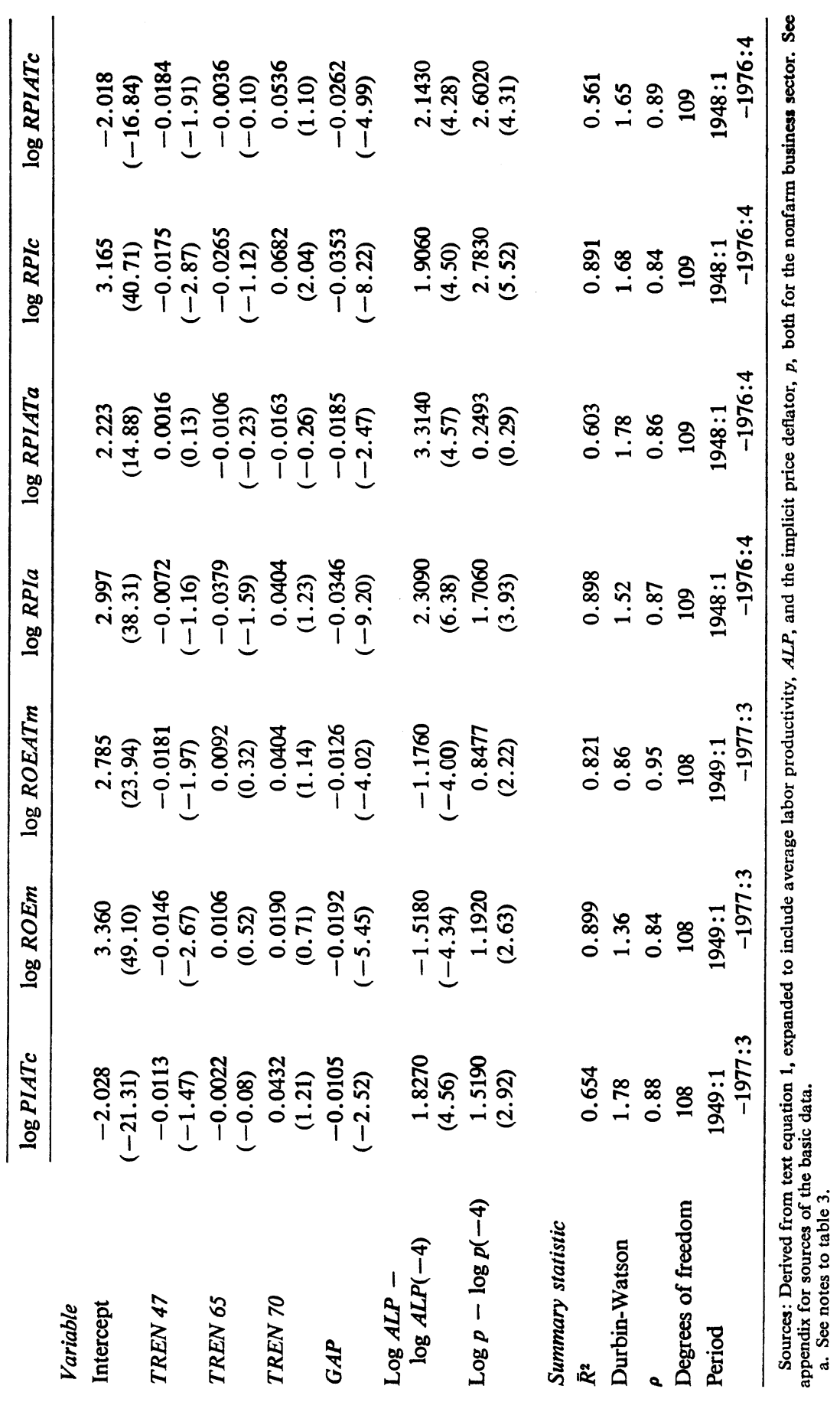


Table 5. PIa Share of Profits, Actual and with Cycle, Productivity, and Inflation Adjustments, 1949-77

Percent

\begin{tabular}{|c|c|c|c|c|}
\hline \multirow[b]{2}{*}{ Year } & \multirow[b]{2}{*}{ Actual } & \multicolumn{3}{|c|}{ Synthetic } \\
\hline & & $\begin{array}{c}\text { Adjusted for } \\
\text { business cycle }\end{array}$ & $\begin{array}{l}\text { Adjusted for } \\
\text { cycle and } \\
\text { productivity }\end{array}$ & $\begin{array}{c}\text { Adjusted for } \\
\text { cycle, produc- } \\
\text { tivity, and inflation }\end{array}$ \\
\hline 1949 & 0.22 & 0.26 & 0.27 & 0.26 \\
\hline 1950 & 0.24 & 0.26 & 0.26 & 0.26 \\
\hline 1951 & 0.24 & 0.23 & 0.24 & 0.22 \\
\hline 1952 & 0.21 & 0.20 & 0.21 & 0.20 \\
\hline 1953 & 0.19 & 0.19 & 0.19 & 0.19 \\
\hline 1954 & 0.19 & 0.20 & 0.21 & 0.21 \\
\hline 1955 & 0.22 & 0.22 & 0.23 & 0.22 \\
\hline 1956 & 0.20 & 0.20 & 0.21 & 0.20 \\
\hline 1957 & 0.19 & 0.20 & 0.21 & 0.20 \\
\hline 1958 & 0.17 & 0.19 & 0.20 & 0.20 \\
\hline 1959 & 0.20 & 0.21 & 0.22 & 0.21 \\
\hline 1960 & 0.18 & 0.20 & 0.21 & 0.21 \\
\hline 1961 & 0.18 & 0.20 & 0.21 & 0.21 \\
\hline 1962 & 0.20 & 0.21 & 0.22 & 0.22 \\
\hline 1963 & 0.21 & 0.22 & 0.23 & 0.22 \\
\hline 1964 & 0.22 & 0.22 & 0.23 & 0.22 \\
\hline 1965 & 0.23 & 0.23 & 0.23 & 0.23 \\
\hline 1966 & 0.22 & 0.21 & 0.22 & 0.21 \\
\hline 1967 & 0.21 & 0.20 & 0.21 & 0.20 \\
\hline 1968 & 0.20 & 0.20 & 0.20 & 0.19 \\
\hline 1969 & 0.18 & 0.18 & 0.19 & 0.17 \\
\hline 1970 & 0.15 & 0.16 & 0.17 & 0.16 \\
\hline 1971 & 0.16 & 0.17 & 0.18 & 0.17 \\
\hline 1972 & 0.17 & 0.17 & 0.18 & 0.17 \\
\hline 1973 & 0.16 & 0.16 & 0.17 & 0.16 \\
\hline 1974 & 0.14 & 0.15 & 0.16 & 0.14 \\
\hline 1975 & 0.16 & 0.19 & 0.20 & 0.17 \\
\hline 1976 & 0.17 & 0.20 & 0.20 & 0.19 \\
\hline 1977 & 0.17 & 0.19 & 0.19 & 0.18 \\
\hline Average & 0.193 & 0.202 & 0.210 & 0.199 \\
\hline Standard deviation & 0.028 & 0.026 & 0.026 & 0.029 \\
\hline
\end{tabular}

Sources: Actual, see appendix; synthetic, see text note 18. Annual averages were computed from quarterly data.

a. See table 1 for definition of $P I a$. 
cycle; the last series adjusts for productivity, cycle, and the estimated effect of inflation. ${ }^{18}$ Inspection of these last two columns suggests that changes in labor productivity and prices have only a minor influence on the historical movements of the profit share. The marked decline in profits during the latter half of the 1960s and the partial recovery in the 1970s remains even after adjustment for the effects of the $G A P$, the slowdown in productivity growth, and inflation.

\section{Summary}

The various profit measures surveyed in this report display diversity in movement over the years; they are not highly correlated. Certain common themes nonetheless stand out. First, by all measures, the profitability of nonfinancial corporations declined gradually over most of the period since World War II. Second, by almost every measure, profits were decisively squeezed during the last half of the 1960s. Thus the Vietnam War period pushed down profitability. Third, profitability has been on a recovery path in the 1970s, although the degree of recoupment varies considerably among the various measures.

The admittedly ad hoc regressions describing the movements of the various profit measures leave a major puzzle for future investigation. It is not surprising to find that profits are sensitive to cyclical forces and thus subject to deterioration in slack times. As expected, a slowdown in productivity growth is bad for profits. And there is no surprise in the finding that rising prices in the corporate sector help profits. The puzzle is that the cycle, fluctuations in productivity growth, and price movements do not explain more fully the trend movements in the various profit measures. The puzzle may arise because the bunching of investment expenditures has implications for subsequent profit movements that are not fully captured by the GAP and productivity variables. The trends, including the squeeze in the late 1960 s, may be associated with variables that can be identified in subsequent work but that are not included in the regres-

18. The synthetic profit shares are calculated from the regression coefficients for the $P I a$ series in table 4 . The cyclically adjusted share is

$$
C A S=\exp (\log P I a+0.01656 G A P) ;
$$

the cyclically and productivity adjusted share is

$$
C P A S=\exp \{\log C A S-3.484[\log A L P-\log A L P(-4)-0.025]\} \text {; }
$$

and the cyclically, productivity, and inflation adjusted share is

$$
\text { CPIAS }=\exp \left\{\log _{2}^{7} C P A S-0.9438[\log p-\log p(-4)]\right\} .
$$


sions in table 4. My suspicion is that a better explanation of these profit trends will require a more detailed structural look at the way in which prices respond to changes in labor and energy costs.

\section{APPENDIX}

\section{Data Sources}

All DATA are from the NBER (National Bureau of Economic Research) data bank, except where otherwise noted. NBER symbols are used in explaining the construction of the profit series. The profit series are for the nonfinancial corporate sector, except for ROEm and ROEATm, which cover only manufacturing.

\section{Profit \\ measure}

$\mathrm{Pa}$

PIa

PATa

PIATa

Pc

PIc

$P A T c$

PIATC

ROEm

ROEATm

RPIa

RPIATa

RPIc

RPIATC

\section{Construction}

Corporate profits with IVA and CCA/domestic income of nonfinancial corporations (GJJVA/GJY)

Corporate profits plus interest/domestic income (GJJVA + GJINT)/GJY Corporate profits after tax/domestic income (GJJVA - GJTAX)/GJY

Profits and interest after tax/domestic income (GJJVA + GJINT - GJTAX)/GJY

Profit share, businessmens' convention (GJPBT/GJYBC where GJYBC = GJPBT + GJINT + GJCOMP is conventionally measured income)

Profit plus interest share (GJPBT + GJINT)/GJYBC

Profits after tax, businessmen's convention (GJPBT - GJTAX)/GJYBC

Profits and interest after tax (GJPBT + GJINT - GJTAX)/GJYBC

Before-tax return on equity, approximated by calculating ROEBT = ROEAT • GJPBT/(GJPBT - GJTAX)

After-tax return on equity, FTC, ${ }^{19}$ smoothed in accordance with Perry's procedure

Profits with IVA and CCA/capital stock (GJJVA + GJINT)/IPXQ, where IPXQ is Musgrave's estimate of equipment plus structures of nonfinancial corporations (Survey of Current Business, April and August 1976, and August 1977)

Profits plus interest after tax/capital stock (GJJVA + GJINT - GJTAX)/ IPXQ

Profits, businessmens' convention/capital stock (GJPBT + GJINT)/ IPXQ

Profits, businessmens' convention, plus interest after tax/capital stock (GJPBT + GJINT - GJTAX)/IPXQ

19. After-tax return on equity is from Federal Trade Commission-Securities and Exchange Commission, Quarterly Financial Report for Manufacturing Corporations, and (since 1971) FTC, Quarterly Financial Report for Manufacturing, Mining and Trade Corporations, various issues. 


\section{Discussion}

THE PANEL discussed some of Lovell's alternative profit measures. John Shoven said that profit measures that fail to include interest payments are biased. And the bias is most serious in those measures that purport to adjust for inflation because they adjust only the asset side of the accounts. Inventories and depreciable assets are corrected for the effects of inflation while capital gains on the firm's liabilities are neglected. Shoven believed this might explain why the series that include interest have smoother time trends. Lovell concurred. Arthur Okun found the return on equity the least defensible measure of profitability because the denominator had no clear meaning in a time of changing prices. Laurence Seidman noted, however, that the after-tax rate of return on equity showed no evidence of a squeeze during the past decade when wages accelerated and argued that it, rather than the adjusted indicators of profitability devised by economists, might have been relevant to wage determination. Although Lovell found that argument plausible, he reported that the return on equity had not performed as well in wage equations as conventionally measured profits plus interest. Albert Rees said there was little evidence that any measure of profitability belonged in a wage equation. He believed profits proxied for other cyclical variables when they were used in econometric wage equations.

Shoven discussed Lovell's complaint that constant-dollar FIFO accounting did not measure the gains on speculative inventory holdings. He argued that no single system of accounting could serve all measurement purposes. He reasoned that cost accounting should give a backwardlooking summary of what had happened to the firm rather than a view of prospective profitability. Constant-dollar FIFO leads approximately to a measure of the real gain from holding inventory in the past.

Okun questioned Lovell's interpretation of the price-change variable in his profits equation as measuring the effect of inflation. It was not surprising that a rising deflator for the corporate sector improved profitability. But whether general price inflation did so would depend on where it originated. Inflation that came from supply-side disturbances to materials costs might narrow profit margins instead. Lovell replied that distinguishing the source of the inflation with a profit equation would be difficult and that adding materials costs to an equation with prices and productivity virtually reduced it to an identity. 